\title{
Titae
}

30 (2016) 277-293

Jerzy Gocko SDB

Katolicki Uniwersytet Lubelski Jana Pawła II

Jerzy@Gocko.pl

\section{Troska KościoŁa o pOKÓJ. \\ PERSPEKTYWA TEOLOGICZNOMORALNA}

The Church's Concern for Peace.

The Moral-theological Perspective

Artykuł ukazuje z perspektywy teologicznomoralnej najważniejsze aspekty zaangażowania Kościoła na rzecz pokoju. Wstępne rozważania na temat istoty pokoju, odniesione do kategorii dobra wspólnego oraz postrzegające pokój jako istotny element ładu społecznego, który ze swej natury ma charakter ładu moralnego, ukierunkowały główny nurt refleksji na wymiar personalistyczny i etyczny. Z kolei odniesienie pokoju do prawdy pozwoliły powiązać go z ideą praw człowieka. Wskazano także na konieczność odideologizowania troski o pokój, co charakteryzuje niektóre współczesne nurty pacyfistyczne. Naukowe analizy potwierdziły, że katolicka koncepcja pokoju zbudowana jest na bazie antropologii personalistycznej. Fundamentem pokoju, na którym osadzone jest całe życie społeczne, jest osoba ludzka.

pokój, prawa człowieka, nauka społeczna Kościoła, teologia moralna, pacyfizm 
The article shows the most important aspects of the Church's commitment to peace from the perspective of the moral theology. Preliminary considerations on the essence of peace referred to as the category of the common good and perceived as an important element of the social order, which by its nature stands for the moral order, directed the main current of reflection towards the personalistic and ethical dimensions. The compilation of peace and the truth allowed to combine the moral order with an idea of the human rights. It has been also indicated that the concern for peace ought to be free from ideology, which characterises some of the contemporary pacifistic movements. Scientific analysis confirmed that the Catholic concept of peace is built on the basis of the personalistic anthropology. The human person is the ultimate foundation of peace, upon which the entire social experience is built.

peace, human rights, the social doctrine of the Church, moral theology, pacifism

Problematyka wojny i pokoju zajmowała i zajmuje ważne miejsce zarówno w nauczaniu społecznym Kościoła, jak i w katolickiej refleksji teologicznomoralnej oraz etycznospołecznej, czego wymownym przykładem może być wyodrębnienie tej kwestii w strukturze najważniejszego dokumentu dotyczącego posłannictwa Kościoła w świecie, a mianowicie w Konstytucji duszpasterskiej o Kościele w świecie współczesnym Gaudium et spes Soboru Watykańskiego II ${ }^{1}$. Trzeba jednak podkreślić, że choć oba zagadnienia w społecznej doktrynie Kościoła

1 Por. Rozdział V: Popieranie pokoju i rozwijanie wspólnoty narodów, który składa się z dwóch sekcji: Unikanie wojen oraz Budowanie wspólnoty międzynarodowej ( $\mathrm{nr}$ 77-82). 
i w towarzyszącym jej teologicznym namyśle najczęściej były ze sobą skorelowane, to jednak myśl społeczna Kościoła obecnie przyznaje priorytet nauczaniu na temat pokoju.

$\mathrm{Z}$ perspektywy historycznej można nawet stwierdzić, że przez stulecia w etyce społecznej dominował problem godziwości wojny, a dokładniej analizy dotyczyły koncepcji wojny sprawiedliwej, co już pokazuje, że dostrzegano w wojnie nie tylko zjawisko społeczne, ale przede wszystkim fakt etyczny, dzięki czemu podlega ona także moralnej ocenie. Nigdy jednak nie była uznawana i oceniana jako dobro lub wartość, co najwyżej może być ona w niektórych przypadkach uznana za obronę wartości, a tym samym usprawiedliwiona. Począwszy od nauczania Piusa XII, a zwłaszcza Jana XXIII główny nurt wypowiedzi Magisterium Kościoła, a także podejmowane naukowe badania w tej szerokiej problematyce zaczęły oscylować wokół zagadnienia pokoju. Pokój bowiem uważany jest za fundamentalną wartość dla życia człowieka jako jednostki i wspólnoty osób.

\section{Pokój jako istotny wymiar dobra wspólnego CAEEJ LUDZKOŚCI}

Zagadnienie pokoju należy do najbardziej złożonych i niejednoznacznych pojęć w myśli ludzkiej. Tę szeroką perspektywę semantyczną można rozciągnąć między pojęciem pokoju jako zawieszeniem broni podczas wojny, właściwym dla klasycznej myśli grecko-łacińskiej, a wizją pokoju jako pełni życia i wypełnienia sprawiedliwości, co z kolei głosi tradycja judeochrześcijańska. W biblijno-teologicznej perspektywie prawdziwy pokój ostatecznie jest darem Boga, wyjednanym dla świata i ludzi przez posłuszeństwo Jezusa całkowicie oddającego się Bogu (J 14,27; 20,19-23). Człowiek osiąga ten dar poprzez ufną modlitwę oraz sprawiedliwość (Ps 85,9-14; Iz 32,17;Jk 3,18)².

2 Por. Léon-Dufour, „Pokój”, 700-705. 
We współczesnej teologii katolickiej i wypowiedziach Magisterium Kościoła, począwszy od Jana XXIII, kładzie się nacisk na wzajemną zależność między darem duchowego pokoju a zobowiązaniem chrześcijan do tworzenia podstaw pokoju społecznego i politycznego. Pokój jako Boży dar, mający początek w ludzkich sercach, musi znaleźć swoje przedłużenie w strukturach społecznych, musi przetwarzać całą tkankę życia indywidualnego i zbiorowego. Nie każdy jednak - jak zauważa Paweł Góralczyk - dysponuje tymi samymi możliwościami działania i posiada jednakowy wpływ na powstawanie klimatu pokoju, ale „każdy ma obowiązek znalezienia własnej drogi we wspólnym dziele jego budowania; drogi będącej realizacją ewangelicznej miłości i wolności oraz ewangelicznie rozumianego przebaczenia i pojednania" ${ }^{3}$. Na przekonaniu tym opiera się nie tylko refleksja teologiczna, ale także i praktyczne zaangażowanie się Kościoła w głoszenie pokoju i pielęgnowanie oraz wzbudzanie współpracy między ludźmi i narodami.

Podkreślając troskę Kościoła o pokój, należy już w tym miejscu zauważyć, że nie jest to głoszenie kultu pokoju „za wszelką cenę", czyli kosztem fundamentalnych wartości moralnych człowieka i społeczeństwa. Etyka pokoju daleka jest od bezkrytycznego pacyfizmu, bowiem utrzymanie pokoju za wszelką cenę może prowadzić do różnego rodzaju kapitulacji, także do rezygnacji ze sprawiedliwości i z obrony praw człowieka. Co więcej, może prowadzić do rozzuchwalenia niesprawiedliwych agresorów i dać im jeszcze szersze pole do niszczącego działania. Rezygnacja z przeciwstawiania się skutecznie aktom przemocy może prowadzić do jeszcze większej przemocy. Ojcowie ostatniego Soboru z dużą dozą realizmu przypominają w tym kontekście, że „całej historii ludzkości towarzyszy [...] ostra walka przeciwko mocom ciemności, która rozpocząwszy się na początku świata, będzie trwała, jak mówi Pan, aż po dzień ostatni”‘ .

3 Por. Góralczyk, „Pokój”, 398.

4 Por. Sobór Watykański II, Gaudium et spes, nr 37. 
Osiągnięcie i utrzymanie pokoju - który nie jest jedynie brakiem konfliktów i wojny - jawi się jako wielkie i nieustanne wyzwanie naszych czasów. „Pokoju nigdy nie osiąga się raz na zawsze, lecz należy go budować bezustannie" 5 - przypomina Vaticanum II. A ktualność tego wezwania już objawiła się w trzecim tysiącleciu w sposób niezwykle dramatyczny. Dotyka ludzi bezpośrednio, nawet jeśli „teatry wojny” grane są poza granicami zamieszkałych przez nich krajów i kontynentów. Jak to przed laty w jednym z orędzi na Światowy Dzień Pokoju pisał Jan Paweł II: „możliwy jest tylko jeden pokój” jest on bowiem „wartością, która nie zna podziałów”.

\section{G£ÓWNE RYSY WSPÓ£CZESNEGO NAUCZANIA KoŚCIOŁA O POKOJU}

Wydany w 1992 r. Katechizm Kościoła Katolickiego definiuje pokój jako „trwałość i bezpieczeństwo sprawiedliwego porządku" i ukazuje go - obok poszanowania osoby ludzkiej oraz dobrobytu społecznego i rozwoju - jako jeden z trzech istotnych elementów dobra wspólnego ${ }^{7}$. Katechizm dodaje także, że te trzy elementy dobra wspólnego należy odczytywać integralnie, są one bowiem wzajemnie uwarunkowane. Bez poszanowania osoby ludzkiej, a więc i jej praw, ale i bez zapewnienia określonego poziomu dobrobytu i dania szans prawdziwego rozwoju, nie będzie pokoju i nie będzie prawdziwej troski o dobro wspólne. Podobnie bez pokoju nie można w pełni uszanować osoby i jej praw, a zapewnienie jej dobrobytu i rozwoju staje się niemożliwe lub przynajmniej w poważnym stopniu ograniczone. Widać tu wzajemną zależność między prawem do pokoju a pozostałymi prawami człowieka. Przestrzeganie praw człowieka jest warunkiem

5 Tamże, nr 78.

6 Por. Jan Paweł II, Orędzie na XIX Światowy Dzień Pokoju (1986), nr 1.

7 Katechizm Kościota Katolickiego, nr 1909. 
pokoju. Z drugiej zaś strony bez pokoju niemożliwe jest poszanowanie praw człowieka. Pokój jest niejako warunkiem wstępnym - koniecznym, choć niewystarczającym - przestrzegania praw człowieka, a prawo do pokoju jest w pewnym sensie gwarancją poszanowania wszystkich innych praw ${ }^{8}$.

Drugą cechą charakteryzującą współczesne nauczanie Kościoła katolickiego dotyczące pokoju, jest wpisanie go w szerszą perspektywę ładu społecznego, który ze swej natury ma charakter ładu moralnego. W tym świetle przywołuje się sformulowane w encyklice Pacem in terris przekonanie, że trwały pokój opiera się na czterech filarach - fundamentalnych wartościach, a zarazem zasadach ładu społecznego, które od czasów Jana XXIII zwykło się nazywać „czworobokiem Janowym". Chodzi tu o prawdę, wolność, sprawiedliwość i miłość społeczną, czyli solidarność ${ }^{9}$. Jan Paweł II tak streszcza ten „czworobok Janowy” w odniesieniu do pokoju:

- „Prawda będzie fundamentem pokoju, jeśli każda jednostka uczciwe uświadomi sobie, że oprócz własnych praw ma również swoje obowiązki wobec innych.

- Sprawiedliwość będzie budowała pokój, kiedy każdy w sposób konkretny będzie starał się o poszanowanie praw innych i o wypełnienie własnych obowiązków wobec nich.

- Miłość będzie zaczynem pokoju, kiedy ludzie odczuwać będą potrzeby innych jak swoje własne i dzielić się będą z nimi tym, co posiadają, poczynając od wartości duchowych.

- Wreszcie wolność będzie owocnie podtrzymywać pokój, jeśli wybierając metody osiągania go, pójdą oni za wskazaniami rozumu i odważnie przyjmą odpowiedzialność za własne czyny"10.

Te cztery filary wyrażają i streszczają wszystko to, co można powiedzieć o budowaniu ładu społecznego opartym na posza-

8 Por. Nagórny, „Prawo do pokoju”, 240-241.

9 Por. Jan XXIII, Pacem in terris, nr 35-37.

10 Jan Paweł II, Orędzie na XXXVI Światowy Dzień Pokoju (2003), nr 3. 
nowaniu godności osoby ludzkiej i trosce o dobro wspólne. Dzięki nim wezwanie do zachowania pokoju, który nie jest dany raz na zawsze, nabrało niezwykle wyraźnych kształtów. Nie chodzi bowiem o jakikolwiek pokój, lecz o porządek i ład w życiu społecznym i międzynarodowym oraz o takie bezpieczeństwo dla wszystkich, które opiera się na prawdzie i sprawiedliwości, znajduje wyraz w poszanowaniu wolności, a odsłania swoje najpełniejsze oblicze w miłości. Budowanie życia społecznego na tych filarach ładu społecznego jest też najlepszym zabezpieczeniem przed agresją, przemocą, wojną i wszelkimi konfliktami zbrojnymi. Nie wolno jednak nie widzieć, że przemoc i agresja stale towarzyszy relacjom międzyludzkim; przybiera także postać konfliktów zbrojnych w skali międzynarodowej. Zarówno w skali poszczególnych państw, jak i na forum międzypaństwowym dość często przybiera postać przemocy strukturalnej ${ }^{11}$.

\section{PoKóJ A PRAWDA O CZŁOWIEKU}

Warto zatrzymać się nad odniesieniem pokoju do prawdy, po raz pierwszy tak wyraźnie sformułowanym przez Jana XXIII w encyklice „Pacem in terris”. Znajduje ono bowiem swoje głębokie uzasadnienie na płaszczyźnie ontologicznej. Dzieje się tak, ponieważ natura obu tych rzeczywistości wykazuje cechy analogiczne. W jednym i drugim przypadku można wskazać na ich absolutny (boski) i moralny (ludzki) charakter. Autentyczne przywiązanie do prawdy znajduje swoje odbicie w coraz ściślejszej więzi z Bogiem i sprzyja kształtowaniu się coraz bardziej solidarnych relacji międzyludzkich: jest więc źródłem pokoju ${ }^{12}$.

11 Por. Nagórny, „Prawo do pokoju”, 244-250.

12 Por. Jan XXIII, Pacem in terris, nr 86-90. Por. także: Jan Paweł II, Orędzie na XXXVI Światowy Dzień Pokoju (2003), nr 3. 
Powiązanie prawdy z pokojem pozwala rozpoznać ten ostatni jako owoc wielu postaw oraz zasad etycznych opartych na orędziu Ewangelii, co charakteryzuje współczesną refleksję Kościoła na temat pokoju. Jan Paweł II wyrażał głębokie przekonanie, że prawda umacnia pokój od wewnątrz, ilekroć prowadzi do pełnego poszanowania człowieka w jego naturze i przeznaczeniu ${ }^{13}$. Staje się ona wówczas źródłem zbalansowania odniesień między prawami przysługującymi człowiekowi jako człowiekowi i skorelowanymi z nimi obowiązkami, które mają na względzie konieczność uszanowania godności osoby ludzkiej. W konsekwencji więc u genezy prawa do pokoju nie stoi ani wola społeczeństwa, ani decyzja państwa. Fakt bycia podmiotem prawa do pokoju nie jest również uzależniony od społecznego czy państwowego statusu człowieka. Racja prawa do pokoju tkwi w statusie należnym osobie ludzkiej.

W tym kontekście Benedykt XVI w Orędziu na Światowy Dzień Pokoju z 2006 r. przywołał definicję pokoju św. Augustyna jako tranquillitas ordinis, czyli jako rzeczywistość płynącą z ładu, który znajduje swoją lokalizację w boskim rozumie. Pokój oznacza więc sytuację, ,która ostatecznie pozwala szanować i realizować w pełni prawdę o człowieku"14.

To odwołanie się do prawa naturalnego i prawa wiecznego, które stoi ponad prawem stanowionym poszczególnych państw i wspólnot międzynarodowych, należy uznać za czynnik sprzyjający integracji ludzkiej rodziny, co z kolei ma ogromne znaczenie dla osiągnięcia radykalnego postępu na drodze do zbudowania pokoju. Sprzężenie pokoju z pełną prawdą o człowieku, a więc z odkrywaniem własnej tożsamości we wszystkich wymiarach jego egzystencji, nie jest wyrazem idealistycznej retoryki dokumentów papieskich, lecz stanowi świadectwo wierności kompleksowej i spójnej

13 Por. Jan Paweł II. Orędzie na XIII Światowy Dzień Pokoju (1980), nr 2, 5. Por. także: Juros, „Prawda jako warunek pokoju w nauczaniu Jana Pawła II, 78-98.

14 Por. Benedykt XVI, Orędzie na XXXIX Światowy Dzień Pokoju (2006), nr 4. 
koncepcji człowieka, któremu przyszło żyć w świecie naznaczonym przemocą i wojnami. W tożsamość człowieka musi zostać wpisana także prawda o jego grzeszności, która oddala, ale nie przekreśla, perspektywę stworzenia społeczeństwa idealnego, wolnego od przemocy, wojen i ucisku, gdyż trudno uleczyć ludzi z pokusy egoizmu. Nie zwalnia to jednak Kościoła z przepowiadania Ewangelii nadziei, która zakłada wiarę w zdolności człowieka do podejmowania wysiłków w zakresie pokoju dzięki jego odrodzeniu w prawdzie przez pojednanie z Bogiem, z samym sobą i z innymi, które dokonuje się w Chrystusie, objawiającym pełnię prawdy. Pokój nie należy do kategorii dóbr łatwych, a jego osiągnięcie w życiu społecznym domaga się wstąpienia na drogę znaczoną trudem i koniecznością cierpliwości.

Należy w tym miejscu zauważyć odległy od ideologizacji, a wręcz głęboko realistyczny charakter nauczania Kościoła o pokoju. Dążenie do pokoju ze strony człowieka stanowi dla niego wezwanie do zaangażowania w odkrycie własnej tożsamości, a tym samym do poznania własnej natury. W obliczu opowiedzenia się za pokojem zostaje on sprowokowany do konfrontacji z samym sobą, ze swoja naturą, ze swoim własnym projektem życia, czy w końcu z przejawami kultury, którą wokół siebie odkrywa i sam tworzy. Jan Paweł II w tym kontekście stwierdza, że pytanie człowieka o wartość pokoju musi ostatecznie łączyć się z namysłem nad sensem własnej egzystencji w jej wymiarze osobistym i wspólnotowym ${ }^{15}$. Papieska koncepcja pokoju zakłada więc jego zakorzenienie w najgłębszych pokładach ludzkiej osoby, gdzie rozstrzyga się stosunek człowieka do dobra, do innych i w ostateczności również do Boga ${ }^{16}$.

Papieże okresu posoborowego, w tym zwłaszcza Jan Paweł II i Franciszek, dostrzegając obecne w religiach dążenie do

15 Por. Jan Paweł II, Orędzie na XV Światowy Dzień Pokoju (1982), nr 3. 16 Por. Jan Paweł II, Orędzie na XVII Światowy Dzień Pokoju (1984), nr 2. 
pokoju i organizując modlitewne spotkania w intencji pokoju przedstawicieli różnych religii, wskazują na ludzką naturę jako miejsce, gdzie rodzi się pragnienie życia w pokoju. Oznacza to, że podstawę dla zbudowania pokoju należy upatrywać nie tyle w założeniach filozofii politycznej, systemu ekonomicznego czy wyznania religijnego, ile raczej w rzeczywistości opartej na zapewnieniu godności i praw każdej osoby ludzkiej. Tak ścisłe powiązanie pokoju z ludzką naturą wskazuje - jak już wspomniano - na moralny charakter pokoju. Choć w dyskursie na temat pokoju ważne są uwarunkowania społeczno-polityczne, techniczno-ekonomiczne czy militarne, które znacząco wpływają na jego kształt, to jednak w porównaniu z odniesieniami antropologiczno-etycznymi nie mają one pierwszorzędnego charakteru. Pokój jest przede wszystkim wydarzeniem o charakterze moralnym ${ }^{17}$.

Przedstawione powyżej analizy potwierdzają, że katolicka koncepcja pokoju zbudowana jest na bazie antropologii personalistycznej. Fundamentem pokoju, na którym nabudowane jest całe życie społeczne, jest osoba ludzka. Oznacza to, że pierwszym zagrożeniem ładu społecznego jest spłaszczenie horyzontu życia ludzkiej osoby i utrata przez człowieka własnej tożsamości, czego następstwem będzie również spłaszczenie horyzontu ludzkiego pokoju.

\section{KONIECZNOŚĆ ODIDEOLOGIZOWANIA TROSKI O POKÓJ}

Kościół - jak już wspomniano - w swojej trosce o pokój odwołuje się do integralnej koncepcji osoby ludzkiej, co nadaje jego przesłaniu wymiar profetyczno-krytyczny i zarazem realistyczny. Daleki jest on jednak od postawy skrajnego

17 Por. Jan Paweł II, Orędzie na XXV Światowy Dzień Pokoju (1992), nr 2; tenże. Orędzie na XIX Światowy Dzień Pokoju (1986), nr 1; Franciszek, Orędzie na XLVII Światowy Dzień Pokoju (2014). 
pacyfizmu, który należy traktować jako formę ideologizacji starań o pokój. Tradycja katolicka w głównym swym nurcie nie traktowała prawa do obrony jako czegoś obcego myśli chrześcijańskiej, lecz broniła go, odnosząc do aktualnych warunków kulturowych i historycznych, które zawsze naznaczone są grzechem ${ }^{18}$.

Jedynie w pierwszych wiekach Kościoła można wskazać na pacyfizm jako cechę wyróżniającą chrześcijan. Ta postawa wyrzeczenia się przemocy wynikała z prostego przeniesienia ewangelicznego orędzia miłości zawierającego w sobie postulat aktywnego unikania przemocy na gruncie złożonej sytuacji społeczno-politycznej. Ewangelia niesie jasne przesłanie unikania przemocy, czemu w sposób zdecydowany dał wyraz Chrystus w Kazaniu na Górze. W tym samym duchu interpretowano słowa skierowane do św. Piotra: „Schowaj swój miecz do pochwy, bo wszyscy, którzy za miecz chwytają, od miecza giną" (Mt 26, 5) $)^{19}$. Pierwotni chrześcijanie żyli w głębokiej świadomości, iż są w ramach rzymskiego imperium jedynie „cudzoziemcami”, a ich troską była walka duchowa i oczekiwanie na rychly powrót Chrystusa wraz z nadejściem królestwa Bożego, które dopiero miało stać się ich ojczyzną. Nie odczuwali powołania do obrony cesarstwa z bronią w ręku. Przez wielu, m.in. przez Tertuliana, odmowa zabijania była traktowana jako imperatyw absolutny. Właściwą postawą człowieka wierzącego było przede wszystkim męczeństwo ${ }^{20}$.

Oczywiście należy rozróżnić pacyfizm widziany jako stanowisko teoretyczne (filozoficzne, moralne i religijne) oraz jako ruch społeczny ${ }^{21}$. Według hiszpańskiego moralisty Julio de la Torre, we współczesnym świecie wysuwany przez różne ruchy pacyfistyczne aksjomat niestosowania siły jest niejednokrotnie przejawem wzniosłych ideałów oderwanych

18 Por. Góralczyk, „Rewolucja bez przemocy”, 84.

19 Góralczyk, „Rewolucja bez przemocy”, 82.

20 Por. De la Torre, „Drogi pokoju”, 93.

21 Por. Zwoliński, Wojna. Wybrane zagadnienia, 263. 
od rzeczywistości polityczno-społecznej i warunków historycznych $^{22}$. W tym samym duchu, co jest zgodnie z oficjalną doktryną Kościoła, wypowiada się także wspomniany już polski moralista Paweł Góralczyk, gdy konstatuje: „W świecie, gdzie panoszy się grzech i mnożą się zbrodnie, trzeba niestety, o ile pragnie się zapobiec brutalnej tyranii, przeciwstawić przemoc rozpętaniu przemocy niesprawiedliwej. Gdy przeciwnicy nastają na życie bliźnich, gdy naruszają ich wolność, gdy wykorzystują ich ekonomicznie, gdy depczą ich godność - łamiąc podstawowe prawa osobowe - wtedy trzeba w miarę możliwości przyjść im z pomocą. Te objawy brutalności, którym należy przecież położyć kres zgodnie z obowiązkiem miłości bliźniego będą [...] występować [...] bezkarnie, jeśli przeciwstawi się im jedynie brak przemocy"23.

Do bardzo ciekawych spostrzeżeń doszedł papież Paweł VI, obserwując kontestację wojny w Wietnamie. Dostrzegał z jednej strony oblicze „taktycznego” pacyfizmu, którego celem jest obezwładnienie bądź osłabienie przeciwnika. Taki charakter miało wiele ruchów pacyfistycznych w II poł. XX w. w Europie o charakterze lewicowym, niejednokrotnie inspirowanych i finansowanych przez Związek Sowiecki. $\mathrm{Z}$ drugiej zaś strony wskazywał na oblicze ideologiczne pacyfizmu, który - z kolei - osłabiał w sercach młodych ludzi poczucie sprawiedliwości, obowiązku i ofiary. Dokonał też rozróżnienia stanowiska Kościoła wobec pokoju na świecie od stanowiska pacyfizmu: „Pokój Chrystusowy nie jest lękiem przed siłą i oporem [...], nie jest też podłością, która paktuje z nieszczęściami i niedostatkami ludzi ubogich i bezbronnych" ${ }^{24}$. Pokój nie jest pacyfizmem, lecz wartością, o którą trzeba zabiegać i która, co już podkreślono, przywołując „,czworobok Janowy”, zabezpiecza inne wartości: życie, prawdę, sprawiedliwość, wolność, miłość. Papież czuł obo-

22 Por. De la Torre, „Drogi pokoju”, 93.

23 Góralczyk, „Rewolucja bez przemocy”, 80.

24 Paweł VI, Orędzie na II Światowy Dzień Pokoju (1969). 
wiązek się wypowiedzieć na ten temat, ponieważ ideologia ta wprowadzała rozłamy wewnątrz Kościoła ${ }^{25}$.

W podobnym duchu wypowiadał się Jan Paweł II, dla którego pacyfizm był formą ideologizacji starań o pokój i formą utopi: „chrześcijanin wie, że w ludzkim sercu drzemią skłonności do agresji, do panowania, do manipulowania innymi; wie, że niejednokrotnie podświadomie skłonności te wpływają na motywy działania, nawet mimo deklaracji czy postaw mających świadczyć o nastawieniu pacyfistycznym; chrześcijanin wie, że na ziemi społeczeństwo ludzkie całkowicie pacyfistyczne jest złudzeniem, i że ideologie, które je ukazują jako łatwe do zrealizowania, budzą nadzieje niemożliwe do spełnienia, mają bowiem błędną koncepcję ludzkiej kondycji, nie ujmują problemu w jego całości stosując ucieczkę, ażeby zagłuszyć lęk lub, w innych przypadkach, kierując się własną korzyścią"26. Troska o pokój musi więc prowadzić do odrzucenia pacyfizmu, „za którym często kryje się chęć zapewnienia sobie spokoju za wszelką cenę lub zwykłe tchórzostwo ${ }^{27}$.

Zachowując rezerwę z stosunku do ideologizacji starań o pokój, trzeba z całą mocą podkreślić szczególne zaangażowanie Kościoła w promowanie pokoju. Wyraża się ono w wspieraniu tych inicjatyw, które w szerokiej perspektywie antropologiczno-kulturowej i religijno-społecznej rzeczywiście do niego zmierzają. Czyni to poprzez prewencję, ograniczanie skutków aktualnych działań zbrojnych, jak i powojenną odbudowę. Tam, gdzie to tylko możliwe, nawiązuje współpracę zwłaszcza z instytucjami zaangażowanymi na rzecz ochrony praw osoby ludzkiej. Ten właśnie aspekt jest kluczowy dla światowego pokoju: zarzewie wojny dojrzewa wszędzie tam, gdzie te prawa nie są respektowane ${ }^{28}$.

Szerzej na ten temat: Gianelli - Tornielli, Papieże a wojna, 218-219. Jan Paweł II, Orędzie na XV Światowy Dzień Pokoju (1982), nr 12.

27 Por. Jan Paweł II, Orędzie na XVII Światowy Dzień Pokoju (1984), nr 3.

28 Por. Paweł VI, Orędzie na II Światowy Dzień Pokoju (1969). 


\section{ZAKOŃCZENIE}

Człowiek od zawsze nosił w sobie pragnienie pokoju. Jednak pragnienie to - choć samo w sobie jest czymś szlachetnym - nie wystarcza. Trzeba podjąć solidarną troskę o pokój, wskazywać na jego uwarunkowania, a także stawiać ludziom i całym narodom określone wymagania, by pokój był możliwy i stał się dobrodziejstwem powszechnym.

Jedną z dróg zaangażowania w sprawę pokoju jest wskazywanie na jego zagrożenia. Zadanie to niejako naturalnie wpisuje się w profetyczny charakter posłannictwa Kościoła w świecie, który - jako „ekspert w sprawach ludzkości” - przy pełnym poszanowaniu autonomii rzeczywistości doczesnych, jest w stanie dać światu „to, co jemu jednemu jest właściwe, a mianowicie: uniwersalne spojrzenie tak na człowieka, jak i na sprawy ludzkie" ${ }^{29}$. Tylko Kościól, świadomy możliwych różnych redukcji czy zafałszowań, „ukazuje [...] najgłębszą prawdę o człowieku" 30 .

Ta antropologiczna perspektywa jawi się jako kluczowa. Dzieje się tak, ponieważ różne formy agresji, wojny, terroryzm i inne formy zagrożeń pokoju, nie są rzeczywistościami, które rodzą się poza człowiekiem. Choć przyjmują postać „struktur zła i grzechu", zawsze swoje źródło mają w umysłach i sercach ludzkich. Swoje dogłębne źródło znajdują w podziałach między ludźmi i całymi narodami, które z kolei swój początek mogą brać z błędnie odczytanej wizji człowieka.

Jak pokazano, pokój jest tą rzeczywistością, którą człowiek współczesny afirmuje z zaangażowaniem, które trudno porównać z jakąkolwiek inną rzeczywistością. Ten sam człowiek coraz bardzie zdaje sobie również sprawę, że do zachowania pokoju nie wystarczą już tylko działania na płaszczyźnie politycznej czy ekonomicznej, gdyż rodzi się on z uwzględnienia wymiaru etycznego. Nie będzie prawdziwego

30 Sobór Watykański II, Gaudium et spes, nr 41. 
pokoju, jeśli współczesnego człowieka pozbawi się - wskutek kryzysu tradycyjnych wartości, osłabienia podstawowych struktur społecznych oraz kultury - stałych punktów odniesienia. Oznacza to, że równie ważnym, jeśli nie ważniejszym, zadaniem, oprócz działań zewnętrznych, mających na celu stabilizowanie sytuacji pokoju oraz tworzenie odpowiedniej ku temu infrastruktury (proceduralnej, wykonawczej, jeśli zachodzi taka potrzeba to także militarnej), staje się troska o wewnętrzna strukturępokoju, odczytaną na bazie integralnej koncepcji osoby ludzkiej i obiektywnej hierarchii wartości, a więc w perspektywie etycznej.

Wizja pokoju jako ujęcie antropologiczno-etyczne wynika z głębokiego przeświadczenia, że o jakości świata nie decydują zbrojne armie, ale stan ludzkiego ducha. Trzeba przy tym podkreślić, że konieczność odwoływania się do kategorii aksjologicznych nie skończyła się wraz z upadkiem totalitarnych ideologii XX w., lecz zachowuje wciąż swoją pilną konieczność w odniesieniu do liberalnie zorientowanych społeczeństw demokratycznych, w perspektywie coraz bardziej zaawansowanej globalizacji, a także nowych zjawisk dotykających współczesny świat, w tym zjawisko migracji i wojen o podłożu religijnym. W tym też należy upatrywać szczególną misję Kościoła.

\section{BiBLIOGRAFIA}

Benedykt XVI, Orędzie na XXXIX Światowy Dzień Pokoju 1 stycznia "Pokój w prawdzie” (2006).

De la Torre J., „,Drogi pokoju: krytyczna ocena rozmaitych opcji na rzecz pokoju" (tł. G. Ostrowski), Communio 9/5 (1989) 84-94. Franciszek, Orędzie na XLVII Światowy Dzień Pokoju „Braterstwo podstawa i droga do pokoju" (2014).

Gianelli A., Tornielli A., Papieże a wojna. Od pierwszego światowego konfliktu do ataku na Irak (tt. L. Rodziewicz) (Kraków: Wydawnictwo M 2006). 
Góralczyk G., „Rewolucja bez przemocy”, Communio 14/4 (1994) 74-87.

Góralczyk P., „Pokój”, Jan Pawet II. Encyklopedia nauczania moralnego (red. J. Nagórny, K. Jeżyna) (Radom: POLWEN 2005) 398-402.

Juros H., „Prawda jako warunek pokoju w nauczaniu Jana Pawła II", Communio 7/4 (1987) 78-98.

Jan Paweł II. Orędzie na XIII Światowy Dzień Pokoju „Prawda sita pokoju" (1980).

Jan Paweł II, Orędzie na XV Światowy Dzień Pokoju „Pokój - dar Boga powierzony ludziom" (1982).

Jan Paweł II, Orędzie na XVII Światowy Dzień Pokoju „Pokój rodzi się z serca nowego" (1984).

Jan Paweł II, Orędzie na XIX Światowy Dzień Pokoju „Pokój jest wartościa, która nie zna podziatów Pótnoc-Potudnie, Wschód i Zachód: jest tylko jeden pokój" (1986).

Jan Paweł II. Orędzie na XXV Światowy Dzień Pokoju „Wierzacy zjednoczeni w budowaniu pokoju" (1992).

Jan Paweł II, Orędzie na XXXIII Światowy Dzień Pokoju „Na ziemi pokój ludziom, których Bóg mituje! (2000).

Jan Paweł II, Orędzie na XXXVI Światowy Dzień Pokoju „Encyklika «Pecem in terris» - nieustanne zobowiazanie" (2003).

Jan XXIII, Encyklika Pacem in terris (1963).

Katechizm Kościota Katolickiego (1992).

Léon-Dufour X., „Pokój”, Stownik teologii biblijnej (red. X. Léon-

Dufour, tt. K. Romaniuk) (Poznań: Pallottinum 1990) 700-705.

Nagórny J., „Prawo do pokoju”, Urzeczywistnianie praw cztowieka wXXI wieku. Prawo i etyka (red. P. Morciniec S. L. Stadniczeńko) (Opole: Wyd. UO 2004) 237-263.

Paweł VI, Orędzie na II Światowy Dzień Pokoju „Rozwój praw cztowieka - droga do pokoju" (1969).

Paweł VI, Encyklika Populorum progressio (1967).

Skorowski H., „Problematyka wojny i pokoju w nauce społecznej Kościoła”, Communio 16/4 (1996) 88-103.

Sobór Watykański II, Konstytucja duszpasterska o Kościele w świecie wspótczesnym „Gaudium et spes” (1965). 
Zwoliński A., Wojna. Wybranezagadnienia (Kraków: Wydawnictwo WAM 2003).

Jerzy Gocko, salezjanin, profesor nauk teologicznych, kierownik katedry teologii moralnej społecznej KUL, wykładowca w WSD Towarzystwa Salezjańskiego w Krakowie, redaktor naczelny Seminare oraz Roczniki Teologiczne z. 3: Teologia moralna. 
